\title{
KEKUATAN KOMPETENSI BUDAYA KONSELOR DALAM LAYANAN KONSELING MULTIKULTURAL TERHADAP MASYARAKAT ASEAN
}

\author{
Oleh : Prof. Dr. Firman. MS. Kons. \\ Jurusan Bimbingan dan Konseling FIP Univesitas Negeri Padang \\ Email : firman@konselor.org
}

\begin{abstract}
Kopetensi konselor menghadapi klien di lingkungan masyarakat Asean dipandang sebagai ekuatan pelaksanaan konseling multikultural. Tulisan ini bertujuan menganalisis kekuatan kopetensi konselor dalam membina relasi dengan klien untuk mengembangkan segala potensi yang dimilikinya. Berdasarkan analisis dapat disimpulkan tingkah laku klien dibangun melalui proses sosialisasi berdasarkan nilai budaya yang tumbuh dalam masyarakatnya. Konseling multikultural dapat menjadi pilihan membantu klien mengembangkan segala potensi yang dimilikinya. Relasi konselor dengan klien berjalan dengan lancar, apabila layanan didasarkan oleh kemampuan pengenalan budaya serta kontruksi sosial klien, dibarenggi oleh sikap, kepercayaan, pengetahuan dan keterampilan dalam pemberian layanan konseling multikultural .
\end{abstract}

\section{A. Pendahuluan}

Masyarakat dari berbagai belahan dunia sedang menjalani perubahan sosial budaya yang ditopang oleh berbagai kemajuan teknologi, informasi dan komunikasi. Salah satu kemajuan masyarakat Asean ditunjukan oleh peradaban dalam berinteraksi satu dengan lainnya untuk menyelesai berbagai permasalahan kehidupan. Interaksi antar masyarakat Asean di dalam dan di luar komunitasnya, mengalami perubahan dari caracara konvensional ke on line. Kondisi itu membawa dampak positif dan negatif untuk meningkatkan produktitas, kebahagian dan kesejahteraan.

Keberhasilan Konselor dalam pemberian pelayanan konseling terhadap masyarakat dalam meningkatkan produktifitas, kebahagian dan kesejahteraan sebagai dampak dari perkembangan teknologi informasi dan komunikasi di era Masyarakat Ekonomi Asean (MEA), ditentukan oleh kualitas Sumber Daya Manusia (SDM) Konselor dalam memberikan pelayanan unggul, yang dibarenggi oleh kejujuran, keikhlasan serta kedisiplinan. Jejaringan antar Konselor di lingkungan masyarakat Asean memenuhi kebutuhan masyarakat secara bermitra merupakan kebutuhan dalam 
mewujudkan kerjasama multilateral. Firman (2017) menjelaskan kerjasama multilateral antar masyarakat Asean diarahkan untuk meningkatkan pertumbuhan dan pembangunan, mengatasi tantangan global, termasuk didalamnya ketahanan pangan dan energi, serta stabilitas keuangan internasional.

Masyarakat Asean berasal dari latar belakang budaya yang beragam. Kemajemukan tersebut merupakan kekayaan dan sekaligus dapat dipandang sebagai potensi timbulnya berbagai masalah yang menyebabkan sebagian warga negara mengalami kehidupan sehari-harinya tidak efektif. Pertemuan budaya dalam kemajemukan masyarakat Asean akan terjadi, karena permasalahan silang budaya terkait dengan pola berfikir masyarakat itu sendiri. Individu dan kelompok sosialnya akan selalu mengacu kepada nilai-nilai dalam kebudayaan dari masyarakat mereka sendiri.

Sebagai upaya membatu klien menanggani permasalahannya dalam kontek masyarakat Asean yang majemuk, para konselor dalam pemberian layanan konseling perlu memahami perilaku klien sebagai upaya menjembatani permasalahan silang budaya dalam layanan yang diberikannya. Kondisi ini didasari oleh kebudayaan pada suatu masyarakat merupakan perwujudan kemaknaan klein dalam masyarakat itu sendiri. Setiap klien dalam suatu masyarakat dengan latar budaya berbeda memandang permasalahan yang mereka alami secara unik. Pemahaman konstruksi social yang telah lama dibangun oleh klien dari masyarakatnya perlu dipahami oleh konselor secara mendasar.

Kebudayaan serta masyarakat dimana klien tersebut berada akan selalu berubah sejalan dengan kemajuan pola pikir serta kebutuhannya. Koentjaraningrat (1997 :1994) menjelakan kebudayaan dapat dimaknai sebagai keseluruhan sistem gagasan, tindakan dan hasil karya manusia yang diperoleh melalui hasil belajar dalam kehidupan masyarakat, yang dijadikan milik masyarakat itu sendiri secara kelompok.

Individu beserta masyarakatnya dalam budaya masyarakat majemuk akan mengalami berbagai permasalahan menghadapi berbagai perubahan. Permasalahan silang budaya dalam masyarakat majemuk tidak jarang bersumber dari pola komunikasi, tingkat pengetahuan, status sosial, ekonomi, geografis, adat kebiasaan, 
yang tidak jarang sebagai hambatan dalam menyelesaikan permsalahan kehidupan bersama.

Kondisi masyarakat Asean sebagai masyarakat majemuk, mengalami perubahan dalam berbagai aspek kehidupan. Kontak budaya antar kelompok etnis tertentu dalam masyarakat Asean akan melahirkan perubahan tata nilai atau konflik nilai diantara mereka. Berbagai bentuk permasalahan silang budaya, seharusnya dapat dikendalikan melalui layanan konseling baik di sekolah maupun masyarakat. Melalui tulisan ini menarik dikaji lebih lanjut berkaitan dengan kebudayaan dan tingkah laku klien dan masyarakat majemuk serta kekuatan kopetensi konselor dalam membangun relasi dengan klien berasal dari masyarakat majemuk. Pembahasan permasalahan tersebut bermanfaat bagi konselor untuk membina relasi yang bermakna dalam membantu klien mengembangkan potensi yang dimilikinya

\section{B. Kebudayaan dan Tingkah Laku Klien dalam Masyarakat Majemuk.}

Kebudayaan merupakan pola kehidupan bersama masyarakat yang bersifat dinamis untuk memenuhi kebutuhannya. Masyarakat Asean yang majemuk mempunyai berbagai kebudayaan dan pola perilaku yang berbeda satu dengan lainnya. Kebudayaan yang dibawa klien dari masyarakatnya akan membatasi serta membolehkan mereka melakukan sesuatu yang dianggap pantas dan tidak pantas. Kepantasan klien berperilaku ditentukan oleh sistem nilai budaya mereka masing-masing. Sistem nilai yang telah dibangun oleh klien melalui proses sosialisasi dengan lingkungannya, berfungsi mengontrol serta mengarahkan mereka berperilaku.

Kontak budaya, laju urbanisasi serta perkembangan teknologi informasi menimbulkan dampak yang cukup serius di segala bidang kehidupan klien. Melonggarnya kesadaran kolektif serta melemahnya control social merupakan satu dampak negatif dari perubahan social budaya. Kondisi ini tidak jarang menyebabkan berbagai permasalahan dalam masyarakat, diantaranya : perkelahian, Narkoba/Dadah, perceraian, putus sekolah, kehilangan lapangan pekerjaan dan sebagainya.

Layanan konseling tidak dapat dilepaskan dari kondisi sosial budaya klien itu sendiri. Sebelum layanan konling diberikan, para konselor diharapkan telah memahami berbagai kondisi sosial budaya klien. Pemetaan permasalahan serta kondisi sosial 
budaya klien sangat membantu keefektifan meberikan layanan dan bimbingan yang dibutuhkan klien.

Klien dalam masyarakat majemuk sering dihadapkan oleh pola perilaku yang suatu saat disetujui oleh beberapa kelompok, di sisi lain dicela oleh kelompok lainnya. Perbedaan nilai tersebut tidak jarang menimbulkan berbagai permasalahan yang membutuhkan layanan konseling dalam pemberian pemahaman dan pengalaman untuk menjalani kehidupan yang lebih efektif. Pengalaman seseorang klien melalui layanan dan bimbingan konseling seharusnya tidak hanya sekedar bertambah dalam proses pembentukan kepribadiannya, namun juga terintegrasi dengan pengalaman sebelumnya. Kepribadian klien dengan segala potensinya akan memberikan corak khas pada perilaku dan pola penyesuaian diri mereka dengan lingkungannya.

Hambatan-hambatan potensial dimiliki oleh klien dari masyarakat majemuk untuk memanfaatkan segala potensinya menyelesaikan permasalahan, ditentukan banyak banyak aspek, diantaranya : struktur sosial serta kebudayaan berbeda akan menghasilkan pola dan proses pembuatan keputusan sosial yang berbeda. Masyarakat Asean yang majemuk tersebut, memiliki berbagai kegiatan dan pranata khusus, dimana setiap kultur merupakan sumber nilai yang memungkinkan terpeliharanya kondisi kemapanan dalam kehidupan masyarakatnya.

Klien berasal dari suatu kebudayaan tertentu, cenderung menjadikan kebudayaannya sebagai kerangka acuan dalam berperilaku. Kondisi ini sekaligus akan mengukuhkan jati dirinya sebagai anggota masyarakat yang memiliki karakteristik tertentu. Perbedaan antar budaya, justru bermanfaat dalam mempertahankan dasar identitas diri dan integrasi sosial klien dalam masyarakat tersebut. Pluralisme masyarakat dalam tatanan sosial, agama, budaya dan suku bangsa masyarakat Asean telah berakar dari sejak dahulu kala. Keberagaman budaya dalam kebersamaan serta hidup berdampingan secara damai merupakan kekayaan yang tak ternilai harganya dalam pembangunan masyarakat.

Permasalahan yang sering dihadapi klien dalam masyarakat majemuk yaitu adanya persentuhan dan saling hubungan antara kebudayaan suku bangsa dengan kebudayaan daerah, nasional dan internasional. Diantara hubungan-hubungan ini yang paling kritis adalah hubungan antara kebudayaan suku bangsa dan umum local di satu 
pihak dan kebudayaan nasional serta internasional di pihak lain. Pemaksaan untuk merubah tata nilai atau upaya penyeragaman budaya seringkali dapat memperkuat penolakan klien terhadap layanan konseling yang diterimanya.

Klien tidak jarang merasa curiga dan tidak percaya diri sehingga tidak berani menyampaikan berbagai gejolak/permasalahan yang mereka alami kepada konselor. Keraguan tersebut menyebabkan sebagian besar klien memendam berbagai persoalan hidup yang akhirnya menimbulkan berbagai masalah psikologis maupun fisiologis. Kondisi ini mengakibatkan perbedaan budaya dalam masyarakat manejemuk sebagai hambatan bagi klien dalam menyelesaikan masalahnya.

Layanan konseling yang diterima klien dari konselor seharunya dapat meningkatkan pengetahuan dan pengalaman klien dalam menyelesaikan masalahnya. Penyelesaian permasalahan silang budaya dapat dilakukan dengan membangun kehidupan multi kultural yang sehat. Kondisi ini dilakukan dengan meningkatkan toleransi dan apresiasi antarbudaya, yang dapat diawali dengan peningkatan pengetahuan klien terhadap keberagaman budaya dalam masyarakat

Dengan demikian dapat disimpulkan strategi konseling berbasis sosial budaya dapat menjadi pilihan untuk membantu klien mengembangkan segala potensi yang mereka miliki. Perkembangan klien dengan segala dimensinya merupakan faktor utama sasaran layanan. Konseling berbasis sosial budaya tidak akan melepaskan klien dari prinsip bahwa manusia sebagai subyek sekaligus tujuan dalam setiap langkah dan upaya perubahan dalam masyarakat Asean.

\section{Kekuatan Kopetensi Multikultural dalam Relasi Klien dengan Konselor}

Relasi klien dan konselor dalam layanan konseling dijembatani oleh komunikasi. Komunikasi dalam kajian budaya dipahami sebagai tindakan produksi makna serta negosiasi sistem-sistem makna tersebut oleh individu dalam kebudayaannya. Posisi konelor dalam layanan konseling ditentukan oleh pengetahuan dan kemampuannya untuk menegosiasikan sistem-sistem makna tersebut dengan kliennya dalam berbagai konteks budaya.

Relasi antara konselor dengan klien melalui komunikasi akan dapat meningkatkan kepeduli sosial. Kondisi ini diwujudkan dengan memberi perhatian 
terhadap klien, terutama ditujukan untuk memanfaatkan segala potensi yang dimilikinya untuk memikirkan kepentingan pribadi, kelompok, dan organisasi tertentu.

Djamaluddin Ancok (2013) menjelaskan pengembangan kepeduliaan sosial diperlukan adanya : (1) pikiran positif pada orang lain. Bila seseorang memiliki sifat demikian dia akan melihat orang lain sebagai bagian dari kebahagiaan hidupnya sendiri, (2) kemampuan berempati. Sifat ini dimiliki oleh orang yang bisa merasakan apa yang dirasakan oleh orang lain. Kepekaan perasan yang dimilikinya membuat dia mudah merasakan kegembiraan dan kesusahan orang lain. Orang yang tidak memiliki kemampuan berempati biasanya sangat sulit untuk bisa berhubungan baik dengan orang lain, (3) komunikasi transformasional. Sifat ini dimiliki oleh orang yang selalu memilih kata-kata yang enak didengar telinga di dalam berbicara pada orang lain. Bila terjadi perbedaan pendapat antara dia dengan orang lain, dia tetap memilih kata-kata yang menyejukkan hati dan pikiran dalam menanggapi perbedaan tersebut, (4) berorientasi sama sama puas (win-win). Orang yang memiliki sifat demikian dalam interaksinya dengan orang selalu ingin membuat orang lain merasa gembira dan dia juga gembira. Orang yang demikian memiliki rasa respek pada orang lain, (5) sifat melayani (serving attitude). Orang yang memiliki sifat demikian ini sangat senang melihat orang lain senang dan sangat susah melihat orang lain susah. Sifat ini adalah lawan dari sikap egois yang hanya mementingkan diri sendiri, atau golongannya sendiri. Orang yang memiliki sifat melayani, kalau menjadi pimpinan, dia bukan minta dilayani tetapi melayani kepentingan orang yang dipimpinnya, (6) kebiasaan apresiatif. Orang yang memiliki sifat ini suka memberikan apresiasi pada apa yang dilakukan oleh orang lain. Dengan apresiasi yang diberikan pada orang lain membuat orang lain merasa dihargai. Seorang pimpinan memberikan apresiasi kepada bawahannya biasanya akan menumbuhkan rasa bermakna di dalam kehidupan kerjanya.

Klien berhubungan dengan konselor dalam layanan konseling didasari oleh motif-motif tertentu. Motif-motif tersebut tidak terlepas dari budaya mereka sendiri. Thibault dan Kelley (Firman, 2015) dalam teori pertukaran social menjelaskan seseorang melakukan hubungan secara sukarela dan bertahan dalam hubungan tersebut selama memuaskan ditinjau dari ganjaran yang diperoleh dibandingkan dengan biaya yang dikeluarkan dari hubungan tersebut. 
Ganjaran merupakan nilai positif yang diperoleh klien melalui hubungan social dengan konselor dalam layanan konseling. Ganjaran yang mungkin diperoleh klien dari proses hubungan social tersebut, adalah : berupa penerimaan social, informasi, cinta, pengakuan social dan status. Sedangkan cost atau biaya merupakan akibat negatif yang dikeluarkan klien melalui hubungan sosial dengan konselor dalam layanan konseling. Biaya dalam hubungan social dapat berupa waktu, konflik serta kecemasan, keruntuhan harga diri, tenaga dari kondisi lain yang dapat menimbulkan efek yang tidak menyenangkan.

Kelangsungan hubungan sosial antara konlor dengan klien ditentukan oleh perbandingan antara ganjaran yang diperoleh serta cost yang harus dikeluarkan untuk hubungan tersebut. Seseorang klien tidak segan-segan menghabiskan waktu tenaga serta harga diri untuk mendapatkan pengalaman, keterampilan agar perbaikan kualitas hidupnya di masa mendatang. Apabila pengalaman, keterampilan yang diperoleh sesuai dengan tenaga, waktu dan harapan yang diinginkan terwujud maka hubungan tersebut akan bertahan. Apabila cost atau biaya yang dikeluarkan klien lebih besar dari reward atau ganjaran diperoleh dari sesesuatu hubungan dengan konselor akan upaya pemutusan hubungan social.

Sehubungan dengan hal itu, konselor dalam pemberian layanan terhadap klien perlu mengidentifikasi minat, atau bakat dan motif-motif klien yang berasal dari latar budaya berbeda tersebut, mengigat berfariasinya karakteristik klien. Konselor dalam pemberian layanan konseling dalam seting sekolah dan luar sekolah dituntut memperhatikan klien secara individual dan kelompok beserta keunikan social budaya mereka masing-masing.

Pemeliharaan dan memperteguh hubungan antara klien dengan konselor dalam seting sekolah dan luar sekolah memerlukan tindakan tertentu untuk mengembalikan keseimbangan. Rachmat (Firman, 2015) menjelaskan empat factor yang amat penting dalam memelihara keseimbangan hubungan, yaitu :

(1) keakraban, merupakan kebutuhan akan kasih sayang. Hubungan antar pribadi akan terpelihara apabila klien dengan konselor sepakat menetapkan tingkat keakraban yang telah terbina. 
(2) kesepakatan siapa yang akan mengontrol siapa dan bilamana. Jika dua orang mengambil pendapat berbeda sebelum mengambil kesepakatan siapa yang harus berbicara lebih banyak dan siapa menentukan dan dominan akan terjadi konflik, karena masing-masing mau berkuasa dan tidak ada mau mengalah,

(3) ketepatan respon, artinya klien harus diikuti oleh respon konselor yang sesuai. Pertanyaan harus disambut dengan jawaban, lelucon dengan tertawa dan sebagai. Respon biasanya berkenaan dengan pesan-pesan verbal dan non verbal. Jika pembicaan serius dari seseorang dijawab dengan main-main, ungkapan serius dijawab dengan olok-olok maka hubungan antar pribadi akan mengalami keretakan. Respon yang ditampilkan individu dalam hubungan social terasebut dapat dikategorikan ke dalam respon konfirmasi dan diskonfirmnasi. Respon konfirmasi akan memperteguh hubungan atar peribadi, misalnya dengan memberikan pengakuaan perasaan positif, respon meminta keterangan, respon setuju, sedangkan respon yang bersifat diskonformasi merusak hubungan antar pribadi, misalnya dengan memberikan respon sekilas, respon kosong, respon yang tidak relevan, respon kontradiktif dan sebagainya.

(4) keserasian suasana emosional ketika berlangsungnya hubungan. Jika seseorang berinteraksi dengan seseorang dan individu lainnya dalam suasana emosinal yang berbeda maka interaksi tersebut tidak akan stabil dan besar kemungkinan salah satu fihak akan mengakhiri hubungan atau merubah suasana emosional yang sedang dirasakannya.

Pemahaman kondisi social budaya klien sangat diperlukan oleh konselor untuk meningkatkan kualitas relasi antara konselor dengan klien. Apabila relasi klien dan konselor bersifat dangkal serta kurang terbinanya hubungan interpersonal dengan baik, menyebabkan layanan konseling tidak optimal dalam membina klien untuk mewujudkan kehidupan efektif sehari-hari.

Lee (2008) menjelaskan konselor dituntut memiliki kompetensi berkaitan dengan isu-isu multikultur dan keragaman agar relasi dengan klien berjalan dengan baik. Keragaman dalam masyarakat multikultural menggambarkan dimensi ras/etnis, status social ekonomi, agama/spiritualitas, orientasi seksual, dan status sosial. 
Berkaitan dengan hal itu, Corey (2013) menjelaskan keragaman dalam konseling menunjukan hubungan dua arah arah antar konselor dengan klien secara timbal balik.

Perwujudan hubungan timbal balik yang bermakna antara klien dengan konselor. Roysircar ( Roysircar 2003;(Dillon et al., 2016)menjelaskan kompetensi utama konselor dalam konseling multikultural menyangkut dengan kesadaran diri terhadap sikap dan konstruksi sosial yang dimilikinya. Di sisi lain konselor dituntut memiliki kemampuan mengenali juga sikap dan konstruksi sosial yang dimiliki klien terhadap diri dan lingkungan sosialnya. Rumusan ini menekankan bahwa keberhasilan suatu konseling terletak pada kemampuan konselor mengintegrasikan teori dan pendekatan konseling serta asesmen yang tepat untuk menghadapi keragaman yang ada di dalam diri klien. Kompetensi multi kultural yang dimiliki konselor dalam layanan bimbingan dan konseling menjadi kekuatan utama mencapai keberhasilan layanan yang diberikan konselor terhadap klien dalam mengatasi permasalahannya.

Arredondo, Toporek, Brown, Jones, Locke, Sanches \& Stadler (Rosycar, 2003; Erford, 2007 ;(Ægisdóttir, Gerstein, \& Çinarbaş, 2008) menjelaskan kompetensi konseling multikultutal berisikan domain dan areal kopetensi yang harus dikuasai konselor. Domain kompetensi counseling tersebut, terdiri dari kesadaran konselor tentang nilai dan bias budaya, kesadaran konselor terhadap klien memandang dunianya, strategi dan interpretasi konselor terdahap klien beserta permasalahan yang dialaminya. Sedangkan area kompetensi multikultural konselor, yang terkandung di dalam setiap domain sikap dan kepercayaan, pengetahuan dan keterampilan..

Dengan demikian dapat disimpulkan relasi antara konselor dengan kelien berjalan dengan lancar, apabila layanan yang diberikan konselor didasarkan

pengenalan budaya serta kontruksi sosial yang dimiliki klien. Kopetensi yang seharusnya dimiliki konselor, yaitu kesadaran konselor terhadap nilai dan bias budaya, kesadaran konselor terhadap budaya klien yang dibarenggi oleh sikap, kepercayaa, pengetahuan dan keterampilan dalam pemberian layanan konseling.

\section{Kesimpulan}

Berdasarkan uraian tersebut dapat disimpulkan hal sebagai berikut: 
a. Tingkah laku klien dibangun melalui proses sosialisasi berdasarkan nilai budaya yang tumbuh dalam masyarakatnya. Konseling multikultural dapat menjadi pilihan membantu klien mengembangkan segala potensi yang dimilikinya. Konseling berbasis sosial budaya tidak akan melepaskan diri klien dari prinsip bahwa manusia sebagai subyek sekaligus tujuan dalam setiap langkah dan upaya perubahan.

b. Relasi klien dengan konselor dalam layanan konseling dijembatani oleh komunikasi sebagai tindakan produksi makna serta negosiasi sistem-sistem makna tersebut dalam kebudayaannya. Perhatian terhadap klien beserta kebudayanya ditujukan mengembangkan potensi untuk mewujudkan kebahagian diri, kelompok/organisasinya dan masyarakatnya.

c. Relasi antara konselor dengan kelien berjalan dengan lancar, apabila layanan yang diberikan konselor didasarkan oleh kemampuan pengenalan budaya serta kontruksi sosial klien. Kesadaran konselor terhadap nilai dan bias budayanya beserta klien dengan budayanya, yang dibarenggi oleh sikap, kepercayaa, pengetahuan dan keterampilan dalam pemberian layanan konseling akan menjadi kekuatan dalam pelaksanaan konseling multikultural .

\section{DAFTAR KEPUSTAKAAN}

Ægisdóttir, S., Gerstein, L. H., \& Çinarbaş, D. C. (2008). Methodological Issues in CrossCultural Counseling Research: Equivalence, Bias, and Translations. The Counseling Psychologist (Vol. 36). https://doi.org/10.1177/0011000007305384

Dillon, F. R., Odera, L., Fons-Scheyd, A., Sheu, H. Bin, Ebersole, R. C., \& Spanierman, L. B. (2016). A dyadic study of multicultural counseling competence. Journal of Counseling Psychology, 63(1), 57-66. https://doi.org/10.1037/cou0000118

Firman dan Elisna Sandora (2013) : Efektifitas Pembinaan Anak Jalanan Melalui Rumah Singgah. Padang: Balitbang Propinsi Sumatera Barat. 
Kazdin, A.E. (2001) : Behavior modification: In applied settings $6^{\text {th }}$ ed. Belmont, CA: Wadsworth/Thomson Learning.

Koentjaraningrat. (1997) : Pengantar antropologi pokok-pokok etnografi II. Jakarta: Rineka Cipta. 
MAKALAH

\section{KEKUATAN KOMPETENSI BUDAYA KONSELOR DALAM LAYANAN KONSELING MULTIKULTURAL TERHADAP MASYARAKAT ASEAN}

\section{Oleh}

Prof. Dr. Firman. MS. Kons

(Jurusan Bimbingan dan konseling Fakultas Ilmu Pendidikan

Univ. Negeri Padang)

Disampaikan dalam Seminar pada Hari/Tanggal :

di Padang 
